\title{
Comparison of Environmental Performance of Single-Family House and Multi-Storey Apartment in Turkey using Life Cycle Assessment
}

\section{Sedat Gulcimen}

Abdullah Gül Üniversitesi: Abdullah Gul Universitesi

Nigmet Uzal ( $\nabla$ nimetuzal@gmail.com )

Abdullah Gul University

\section{Tolgahan Varışlı}

Abdullah Gül Üniversitesi: Abdullah Gul Universitesi

\section{Ghaith Khidrah}

Abdullah Gül Üniversitesi: Abdullah Gul Universitesi

\section{Research Article}

Keywords: Life Cycle Assessment, Environmental Impacts, Global Warming Potential, Single-Family House, Multi-storey Building

Posted Date: December 3rd, 2021

DOI: https://doi.org/10.21203/rs.3.rs-1027577/v1

License: (9) This work is licensed under a Creative Commons Attribution 4.0 International License. Read Full License 


\section{Abstract}

In recent years, there has been a significant transition from multi-storey buildings to single-family houses especially due to COVID-19 pandemic. Thus, people prefer to live in single-family houses or detached houses where they have more free space in outside of the house. The aim of this study is to quantify and compare the environmental performance of a single-family house and multi-storey apartment building in Turkey throughout their life cycle with cradle-to-grave approach. Life Cycle Assessment (LCA) based on ISO 14040 and ISO 14044 was used to analyse the environmental impacts of the single-family house and multi-storey apartment buildings. The functional unit was chosen as $1 \mathrm{~m}^{2}$ of floor area of a house over their lifespan (50 years). With cradle-to-grave approach of the LCA, the system boundaries for the environmental assessment covers the pre-operation, operation and post-operation stages. The results of this LCA study revealed that majority of the environmental impacts occurs at operation phase for both single-family house and multi-storey apartment. The operation stage has the highest impact with $79 \%$ and $78 \%$ share of the global warming potential (GWP) for single-family house and the multi-storey apartment, respectively. In comparison of environmental impact results, GWP of the multi-storey apartment per $\mathrm{m}^{2}$ of floor area is $30 \%$ lower than single-family house. The environmental impacts of the operation phase have significant importance on the overall environmental performance of both singlefamily house and multi-storey apartment. The results showed that electricity consumption and steel usage are the main contributors of the environmental impacts coming from the operation and preoperation phases, respectively. To pave the way to a sustainable future, the building industry must strive to use of renewable energy sources and sustainable construction materials in order to reduce their environmental impacts with a sustainable approach.

\section{Introduction}

The building industry has a significant role on quality of human life by constructing buildings and infrastructure to meet the socio-economic needs of individuals, society and nations (Lee et al. 2017). However, building industry accounts for large proportion of global environmental impacts with about 30$40 \%$ of global greenhouse gas (GHG) emissions and $40 \%$ of the energy consumption worldwide (Hollberg and Ruth 2016; Lu et al. 2019; Yung and Wang 2014). Additionally, operation phase of the buildings is an energy-intensive phase. It is reported that buildings are responsible for about $60 \%$ of the global electricity consumption for their operation (Dong et al. 2021). Besides, the energy produced from non-renewable sources is the main contributor to air pollution because of the releasing pollutants such as carbon dioxide $\left(\mathrm{CO}_{2}\right)$, sulfur dioxide $\left(\mathrm{SO}_{2}\right)$ and nitrogen oxides $\left(\mathrm{NO}_{\mathrm{x}}\right)$ which affect the human heath negatively (Elzarka et al. 2017). These pollutants causes climate change, which is a one of the major environmental problem in the world (Chakraborty et al. 2016). Moreover, post-operation, which refers to demolition phase, may lead to significant environmental impacts due to pollutants from construction and demolition wastes, the discharge of hazardous materials and lack of landfill sites (de Magalhaes et al. 2017; Ding et al. 2018).

Life cycle assessment (LCA) is the most commonly used method to quantify the environmental impacts of a product, process or service throughout their life cycle (Chen et al. 2010; Norris 2001). In last decades, 
the researchers put significant effort to analyze and assess the environmental impacts of buildings through LCA for several purposes (Alvarez-Rodriguez et al. 2019; Asdrubali et al. 2013; Blengini and Di Carlo 2010; Hernandez et al. 2019; Konig and De Cristofaro 2012; Lewandowska et al. 2013; Monteiro and Freire 2012; Petrovic et al. 2019; Rossi et al. 2012; Van Ooteghem and Xu 2012; Wang et al. 2018). Asdrubali et al. (2013) applied LCA on three Italian buildings, which are a detached residential house, a multi-family and a multi-storey office building. Their analyses covered the stages from production of construction materials to the end of life of the all materials. They found that operation stage is the greatest contributor with $77-85 \%$ of the total environmental impact (Asdrubali et al. 2013). On the other hand, Monteiro and Freire (2012) implemented LCA on a Portuguese single-family house with seven alternative exterior walls to assess the effect of the walls on the environmental performance of the house during its life cycle. They also revealed that wood-wall has lowest environmental impacts among the other wall alternatives (double wall with facing brick, thermal concrete block wall, autoclaved aerated concrete block masonry) (Monteiro and Freire 2012). Petrovic et al. (2019) studied on LCA of a wooden single-family house in Sweden considering $1 \mathrm{~m}^{2}$ living area in a 100-year perspective. Their results reveal that selection of wood-based materials reduces the carbon dioxide emissions significantly when compared with the non-wood based materials (Petrovic et al. 2019).

An LCA study was performed for residential buildings considering the building per square meter basis in South East of Turkey. The study focused on construction, operation and demolition phases of the residential buildings and the findings showed that emissions of residential buildings varies 1 to $10 \mathrm{t}$ $\mathrm{CO}_{2} / \mathrm{m}^{2}$ (Atmaca 2016). Besides, Mangan and Oral (2015) applied an LCA to determine optimum energy retrofit strategies on residential buildings in Turkey. Their study focused on hot humid and cold climate zones of Turkey, where are Antalya and Gaziantep. They revealed that thermal insulation thickness and thermal transmittance values significantly affects the thermal and environmental performance of the residential buildings (Mangan and Oral 2015). Additionally, Atmaca and Atmaca (2015) implemented an LCA on two residential buildings in Gaziantep, Turkey to estimate total energy use and carbon emissions over a 50-year lifespan. They found that the operation phase is the major contributor in both urban and rural residential buildings and contributes $73-76 \%$ of the energy use and $59-74 \%$ of the carbon emissions, respectively. Their results also showed that the life cycle energy demand in urban residential buildings is $18 \%$ higher than in rural conditions due to different building structure, air conditioning habits and living standards (Atmaca and Atmaca 2015). Previous studies in literature reveal that region of the buildings significantly effects the LCA results mainly due to variation in climate, geographical conditions and material selection.

To the best of the author's knowledge, there is no study conducted to compare the overall environmental impacts of a single-family house and multi-storey apartment building in Turkey. This paper presents the first study in literature about comparison of the environmental performance of a single-family house and multi-storey apartment building by using LCA in Turkey with cradle-to-grave approach. This study addresses the entire life cycle of two residential buildings including pre-operation, operation and postoperation phases. 


\section{Methodology}

In this study, LCA was applied for the comparison of the environmental performance of a single-family house and multi-storey apartment building based on ISO 14040 and ISO 14044 standards which covers four main phases (i) goal and scope definition, (ii) life cycle inventory, (iii) life cycle impact assessment and (iv) interpretation and described below (Finkbeiner et al. 2006).

\subsection{Goal And Scope Definition}

The main goal of the study was to quantify and compare the environmental impacts of a single-family house and multi-storey apartment building in Turkey along their life cycle with cradle-to-grave approach. In this study, the functional unit was chosen as $1 \mathrm{~m}^{2}$ of floor area of a house over their lifespan (50 years). With cradle-to-grave approach of the LCA, the system boundaries for the environmental assessment covers the pre-operation, operation and post-operation stages as indicated in Fig. 1. The pre-operation phase covers raw material extraction, transportation of materials and construction of building while operation phase consists of operation, maintenance and replacement and post operation refers to demolition of the building.

The study uses an example of two-storey single-family house constructed by a local construction company in Kayseri, Turkey. The house consists of two floors (main and basement), about $118 \mathrm{~m}^{2}$ each and total gross area $238 \mathrm{~m}^{2}$. Another case study building is a multi-storey apartment constructed by a local construction company in Kayseri, Turkey. The apartment has 14 floors and each floor consists of two flats (totally 28 flats). The total gross areas of the apartment is $6020 \mathrm{~m}^{2}$ and each flat is $175 \mathrm{~m}^{2}$. Fig. 2. illustrates the $3 \mathrm{D}$ model of the single-family house and multi-storey apartment buildings.

\subsection{Life Cycle Inventory (Lci)}

In this study, primary data for pre-operation and operation phase concerning the amount of raw materials (concrete, steel, cement, lime, sand, gypsum, glass, paint, ceramics, electric cables, pipes, marble, and insulation materials), energy consumption, and transportation were gathered from a local company, which constructs single-family houses and multi-storey apartments in Kayseri, Turkey (Table S1 and S2). The rest of the data for operation and post-operation phases were implemented into the analyses using Ecoinvent v3. database in SimaPro 8.4 PhD version. Electricity, natural gas and water consumption were calculated as a function of average consumption and number of occupants (Table S2). Service life of both single-family house and multi-storey apartment were assessed as 50 years. Moreover, it is assumed that all construction waste will transport to landfill at the end of life of the buildings. The transportation distance of the construction wastes to the landfill is assumed to be $40 \mathrm{~km}$. While interpreting the results of this study, following assumptions and limitations should be considered:

- Any impacts created or avoided by reusing or recycling of construction and demolition were excluded from the scope of the study. It is assumed that all construction waste will transport to landfill at the 
end of life of the buildings. The transportation distance of the construction wastes to the landfill is assumed to be $40 \mathrm{~km}$.

- Service life of both single-family house and multi-storey apartment were assessed as 50 years.

- The inventory data for the case study buildings was collected from a local construction company. For missing life cycle inventory, some assumptions and simplifications were done.

- Machinery and furniture utilized inside of the buildings were not included in this study.

- It is assumed that energy mix and intensities were constant over the building's lifespan.

\subsection{Life Cycle Impact Assessment (Lcia)}

Life cycle impact assessment (LCIA) converts emissions and extractions into a certain number of environmental impact scores, which is called characterization. In this study, the ReCiPe Midpoint $(\mathrm{H})$ method (ReCiPe 2018) was selected for the impact assessment of the single-family house and multistorey apartment. The ReCiPe method consists of totally 18 midpoint impact categories. In this study, the following six impact categories were selected for LCIA: global warming potential (GWP), ozone layer depletion (OLD), human toxicity potential (HTP), acidification potential (AP), eutrophication potential (EP) and land use (LU). In this phase of the LCA, SimaPro 8.4.1 software and Ecoinvent v3. database that supply broader and well-prepared data for various products and processes was used for this study (Ecoinvent 2013). For the characterization and normalization of the environmental impacts of the buildings, global and European database values, which are available in SimaPro software were used.

\section{Results And Discussion}

\subsection{LCA Results of Single-Family House}

The LCA results of a single-family house in Turkey by considering cradle-to-grave approach were calculated using ReCiPe midpoint $(\mathrm{H})$ method and the results were indicated in Table 1. LCA analysis consists of six environmental impact categories (GWP, ODP, AP, EP, HTP and LU) to reveal the environmental performance of the buildings. The value of GWP was calculated as $3.26 \mathrm{E}+03 \mathrm{~kg} \mathrm{CO}$ eq for the single-family house given in Table 1. The main contributor factor for GWP were fossil-based energy consumption for lighting, HVAC, running appliance and maintaining the comfort conditions regularly in the operation phase. Besides, the value of ODP for the single-family house was $6.76 \mathrm{E}+00 \mathrm{~kg}$ NOx eq (Table 1). The usage of vinyl-based materials particularly in window frames for residential buildings and use of CFCs and HCFCs in manufacturing of insulation materials are the main reasons of the ODP impact category (Azari 2014). 
Table 1

Impact category values of single-family house per $\mathrm{m}^{2}$ of floor area (ReCiPe midpoint $(\mathrm{H})$ method)

\begin{tabular}{|lll|}
\hline Impact category & Unit & Single-Family House \\
\hline Global warming potential & $\mathrm{kg} \mathrm{CO}_{2}$ eq & $3.26 \mathrm{E}+03$ \\
\hline Ozone layer depletion & $\mathrm{kg} \mathrm{NO}_{\mathrm{x}}$ eq & $6.76 \mathrm{E}+00$ \\
\hline Acidification potential & $\mathrm{kg} \mathrm{SO}_{2}$ eq & $3.21 \mathrm{E}+01$ \\
\hline Eutrophication potential & $\mathrm{kg} \mathrm{P} \mathrm{eq}$ & $2.94 \mathrm{E}+00$ \\
\hline Human toxicity potential & $\mathrm{kg} \mathrm{1,4-DBC} \mathrm{e}$ & $2.39 \mathrm{E}+02$ \\
\hline Land use & $\mathrm{m}^{2} \mathrm{a}$ crop eq & $6.11 \mathrm{E}+01$ \\
\hline
\end{tabular}

In this study, process-based analysis is used for evaluation of environmental impacts of single-family house. Within the entire life cycle, processes are mainly divided into three categories, which are preoperation, operation and post-operation phases. In pre-operation phase, extraction of raw materials, transportation of materials and construction of single-family house are included in system boundaries. The operation phase consists of operation, maintenance and replacement of the building for service life of 50 years. In operation phase, consumption electricity, natural gas and water, generation of solid waste and wastewater are taken into account for single-family house. Lastly, post-operation phase covers the demolition of single-family house at the end of its life. The operation phase is dominant on the distribution of GWP for single-family house with $79 \%$ and pre-operation follows with $20 \%$ contribution as shown in Fig. 3. These LCA results are comparable with published LCA findings in the literature. For instance, Dara et. al. (2019) performed a LCA study for single-family house in Canada with cradle-to-gate approach. They report that use and operation phase accounts for $85-95 \%$, of the total life cycle impact (Dara et al. 2019). Petrovic et. al. (2019) applied a LCA on a wooden single-family house in Sweden within the life span of 100 years by considering entire life cycle stages. They revealed that in-use stage has highest environmental impact (64\%) and then production and construction stage follows with $30 \%$ and 4\%, respectively (Petrovic et al. 2019). Zhang et. al. (2013) studied on LCA of a two-storey singlefamily house in Vancouver, Canada over 60 years lifespan. Their findings revealed that the major contributor phase is operation with $30-90 \%$ while manufacturing is about $7-51 \%$ and end-of-life accounted less than 1\% impact (Zhang et al. 2014). Atmaca (2017) studied on LCA of post-disaster temporary housing to estimate the total energy use and $\mathrm{CO}_{2}$ emissions and he showed that operation phase is dominant in $\mathrm{CO}_{2}$ emissions of both container houses and prefabricated houses with $96 \%$ and 95\% contribution, respectively (Atmaca 2017).

The distribution of GWP by sub-components of single-family house for operation phase, which is the most dominant phase, is indicated in Fig. 4. In operation phase, electricity made up $87 \%$ of the total GWP for the single-family for GWP were fossil-based electricity consumption for lighting, HVAC (heating, 
ventilation, and air conditioning), running appliance and maintaining the comfort conditions regularly in the operation phase. These obtained results are similar with the literature on the life cycle assessment of single-family houses. Petrovic et. al. (2019) studied on LCA of a wooden single-family house in Sweden within the life span of 100 years and it was found that operational energy use has $64 \%$ share due to high electricity consumption and maintenance phase follows with $16 \%$ share of the total (Petrovic et al. 2019). In Turkey, residential buildings are responsible for approximately $32 \%$ of the total energy demand, after industry sector with $40 \%$ (Atmaca 2016). It is also stated that final electricity consumption per capita increased from 1404 kWh to 2493 kWh between 2001 and 2011 in Turkey. Regarding to this issue, residential buildings have major potential to decrease energy consumption and greenhouse gas emissions (Stephan et al. 2012). Therefore, the building industry must strive to use renewable energy sources in order to reduce their environmental impacts with a sustainable approach.

The distribution of GWP by sub-components of single-family house for pre-operation phase is shown in Fig. 5. In pre-operation phase, most of the GWP is contributed from steel (34\%), concrete (29\%), transportation (17\%), bricks (6\%) and the remaining are the other raw materials used for the construction of buildings. Steel is one of the widely used construction materials due to its well mechanical and physical properties. According to World Steel Association, nearly $50 \%$ of the produced steel worldwide is used in construction buildings and infrastructure (WorldSteelAssociation 2008). However, manufacturing of steel has significant environmental impacts like greenhouse gas emissions to the atmosphere. International Energy Agency reports that global steel production is responsible for $9 \%$ of the global carbon dioxide emissions (IEA 2008). Concrete is another mostly used construction materials due to its strength and durability. After water, concrete is the second most consumed material worldwide (Gagg 2014).

The obtained LCA results are also coherent with the literature on LCA of construction materials for various purposes. Evangelista et. al. (2018) applied an environmental performance analysis for residential buildings using LCA in Brazil. Their results showed that steel and concrete had the largest environmental impacts in almost all categories with contribution ranging from $44-61 \%$ because of their structure's high concentration (Evangelista et al. 2018). Monahan and Powell (2011) studied on an embodied carbon and energy analysis of construction methods by using life cycle assessment approach. They revealed that concrete is the major contributor with $36 \%$ of the embodied carbon among the used construction materials (Monahan \&Powell 2011). Atmaca (2017) studied on LCA of post-disaster temporary housing to estimate the total energy use and $\mathrm{CO}_{2}$ emissions and he showed that steel and concrete are main contributors of $\mathrm{CO}_{2}$ emissions in construction phase. He revealed that share of steel varies from 38-42\% and share of concrete varies from $9-19 \%$ as dominant factors in construction phase (Atmaca 2017).

\subsection{Lca Results Of Multi-storey Apartment}

The environmental impacts of a multi-storey apartment building in Turkey by considering cradle-to-grave approach were calculated using ReCiPe midpoint $(\mathrm{H})$ method and the results were indicated in Table 2 . LCA analysis consists of six environmental impact categories (GWP, ODP, AP, EP, HTP and LU) to reveal 
the environmental performance of the buildings. The value of GWP was calculated as $2.28 \mathrm{E}+03 \mathrm{~kg} \mathrm{CO}$ eq for the multi-storey apartment building given in Table 2. The main contributor factor for GWP were fossil-based energy consumption for lighting, HVAC, running appliance and maintaining the comfort conditions regularly in the operation phase. Therefore, the building industry must strive to use renewable energy sources in order to reduce their environmental impacts with a sustainable approach. Besides, the value of ODP and LU was $5.05 \mathrm{E}+00 \mathrm{~kg} \mathrm{NO}$ eq and $5.80 \mathrm{E}+01 \mathrm{~m}^{2} \mathrm{a}$ crop for the multi-storey apartment building, respectively (Table 2).

Table 2

Impact category values of multi-storey apartment per $\mathrm{m}^{2}$ of floor area (ReCiPe midpoint $(\mathrm{H})$ method)

\begin{tabular}{|lll|}
\hline Impact category & Unit & Multi-Storey Apartment \\
\hline Global warming potential & $\mathrm{kg} \mathrm{CO}_{2}$ eq & $2.28 \mathrm{E}+03$ \\
\hline Ozone layer depletion & $\mathrm{kg} \mathrm{NO}_{x}$ eq & $5.05 \mathrm{E}+00$ \\
Acidification potential & $\mathrm{kg} \mathrm{SO}_{2}$ eq & $2.45 \mathrm{E}+01$ \\
Eutrophication potential & $\mathrm{kg} \mathrm{P} \mathrm{eq}$ & $2.90 \mathrm{E}+00$ \\
Human toxicity potential & $\mathrm{kg} \mathrm{1,4-DBC} \mathrm{e}$ & $2.12 \mathrm{E}+02$ \\
\hline Land use & $\mathrm{m}^{2} \mathrm{a}$ crop eq & $5.80 \mathrm{E}+01$ \\
\hline
\end{tabular}

The process-based analysis is used for evaluation of environmental impacts of multi-storey apartment in this study. The processes are divided into three main categories, which are pre-operation, operation and post-operation phases. The pre-operation phase covers raw material extraction, transportation of materials and construction of building while operation phase consists of operation, maintenance and replacement and post operation refers to demolition of the building. The operation phase is dominant on the distribution of GWP for single-family house with $78 \%$, pre-operation and post-operation follow with $20 \%$ and $1 \%$ contribution as shown in Fig. 6 . These LCA results can be compared with published LCA findings in the literature. Mehta et. al. (2017) applied a life cycle energy assessment of a multi-storey residential building and they showed that the operational energy refers to energy used for heating, cooling, ventilation and electrical appliance account for $84 \%$ of the total life cycle energy with 50 years of service life (Mehta et al. 2017). Asdrubali et. al. (2013) studied on LCA of three conventional Italian buildings and they found that operation phase has largest contribution with $77-85 \%$ to the total impact. They also showed that share of construction phase on total impact varies from $14-21 \%$ as second most contributor phase (Asdrubali et al. 2013).

The distribution of GWP by sub-components of multi-storey apartment for operation phase, which is most dominant phase, is indicated in Fig. 7. In operation phase, electricity accounts for $83 \%$ of the total GWP for the single-family for GWP were fossil-based electricity consumption for lighting, HVAC, running 
appliance and maintaining the comfort conditions regularly in the operation phase. These obtained results are similar with the literature on the life cycle assessment of multi-storey apartment. In a study, LCA of three conventional Italian buildings was performed and it is found that the impact of the electricity consumption ranges from $43-74 \%$ for operation phase mostly due to coal-based power contribution in the electricity grid (Asdrubali et al. 2013). Regarding to this issue, residential buildings have major potential to decrease energy consumption and greenhouse gas emissions (Stephan et al. 2012). Therefore, the building industry must strive to use renewable energy sources in order to reduce their environmental impacts with a sustainable approach.

The distribution of GWP by sub-components of multi-storey apartment for pre-operation phase is shown in Fig. 8. In pre-operation phase, most of the GWP is contributed from steel (40\%), concrete (28\%), transportation (9\%), cables (7\%) and the remaining are the other raw materials used for the construction of buildings. These LCA results are also coherent with the literature on LCA of construction materials for various purposes. Lu et. al (2017) performed a study to compare alternative materials for Australian multi-storey apartment building from environmental and economic perspective. Their results revealed that wooden houses have greater performance than concrete and steel houses in terms of embodied energy and GWP. They also showed that steel and concrete had the largest environmental burden in all impact categories in construction phase (Lu et al. 2017). In a study, a life cycle energy assessment was applied on a multi-storey residential building and they showed that steel (39.2\%), cement (17.9\%), aluminum $(13.8 \%)$ and concrete $(9.2 \%)$ are the major contributors of the life cycle energy in construction phase (Mehta et al. 2017). Monahan and Powell (2011) studied on an embodied carbon and energy analysis of construction methods by using life cycle assessment approach. They revealed that concrete is the major contributor with $36 \%$ of the embodied carbon among the used construction materials (Monahan and Powell 2011).

\subsection{Comparison Of Lca Result Of The Two Buildings}

The comparison of the total environmental impact of the two case studies (single-family house and multi-storey apartment building) is illustrated in Fig. 9. The single-family house shows higher impact when compared with the multi-storey apartment for all impact categories (GWP, ODP, AP, EP, HTP, and LU) primarily because its total gross area is smaller than the multi-storey apartment. Taking this building as a reference $(100 \%)$, a relative comparison of its impact categories and those of the other case study was analyzed (Fig. 9). Although the total mass value of materials increased for multi-storey apartment, the greater gross living area still reduce the final contribution of total environmental impacts per unit area. For GWP, the multi-storey apartment presented the lowest environmental impact (70\%) due to its larger area, average population and fossil-based energy consumption profile compared with the single-family house. The second highest difference between the two building types considered was obtained for the ODP impact category. For ODP, the multi-storey apartment performed 25\% lower impact than the singlefamily house due to its larger gross area, the higher contribution of insulating materials (e.g., glazed windows, vinyl, etc.) over the pre-operation and operation phases and the greater mass value of walls and windows per unit area. 
The distribution of overall LCA results over 50 years lifespan by life cycle phases is shown in Table 3 . The LCA results of the two case studies indicated that the majority of the environmental impacts occur at the operation phase (31-91\%), followed by the pre-operation (9-67\%). The post-operation phase has a negligible impact (less than $2 \%$ ). These LCA results can be compared with published LCA findings in the literature. For instance, Dara et. al. (2019) performed a LCA study for single-family house in Canada with cradle-to-gate approach. They reported that use and operation phase accounts for $85-95 \%$, of the total life cycle impact (Dara et al. 2019). Petrovic et. al. (2019) applied a LCA on a wooden single-family house in Sweden within the life span of 100 years by considering entire life cycle stages. They revealed that in-use stage has highest environmental impact (64\%) and then production and construction stage follows with $30 \%$ and $4 \%$, respectively (Petrovic et al. 2019). Zhang et. al. (2013) studied on LCA of a two-storey singlefamily house in Vancouver, Canada over 60 years lifespan. Their findings revealed that the major contributor phase is operation with $30-90 \%$ while manufacturing is about $7-51 \%$ and end-of-life accounted less than 1\% impact (Zhang et al. 2014). Evangelista et. al. (2018) performed environmental impact analysis for residential buildings in Brazil with LCA tool. They calculated the environmental performance of four Brazilian residential buildings with various typologies with cradle-to-grave approach. Their analysis results showed that operation stage has highest environmental impact varies between $35 \%$ and $93 \%$ of the total impact. In addition, they revealed that pre-operation stage (6-64\%) is the second main contributor stage and post-operation stage (0-6\%) has lowest impact on environmental performance of the residential buildings (Evangelista et al. 2018). Additionally, an LCA of three conventional Italian buildings (a detached house, a multi-dwelling residential building, and an office building) was studied and it is found that operation phase has largest contribution with $77-85 \%$ to the total impact. They also showed that share of construction phase on total impact varies from $14-21 \%$ as second most contributor phase (Asdrubali et al. 2013).

Table 3

Distribution of impact categories by life cycle phase

\begin{tabular}{|lllllll|}
\hline Impact Categories & \multicolumn{3}{l}{ Multi-Storey Building (\%) } & \multicolumn{3}{l|}{ Single-Family House (\%) } \\
\hline & Pre Op. & Op. & Post Op. & Pre Op. & Op. & Post Op. \\
\hline Global warming potential & 21 & 78 & 1 & 20 & 79 & 1 \\
\hline Ozone layer depletion & 27 & 72 & 1 & 26 & 73 & 1 \\
\hline Acidification potential & 13 & 87 & 0 & 9 & 91 & 0 \\
\hline Eutrophication potential & 17 & 83 & 0 & 9 & 91 & 0 \\
\hline Human toxicity potential & 43 & 57 & 0 & 40 & 60 & 0 \\
\hline Land use & 58 & 41 & 1 & 67 & 31 & 2 \\
\hline Pre Op. = Pre-operation; Op.= Operation; Post Op.=Post-operation & & \\
\hline
\end{tabular}

\section{Conclusion}


This study presents the total environmental impacts of a single-family house and multi-storey apartment building in Turkey throughout their life cycle with cradle-to-grave approach. Within scope of the study, the system boundaries for the environmental assessment covers the pre-operation, operation and postoperation stages. In general, the results reveal that the multi-storey apartment has lower environmental impacts per square meter than the single-family house for all impact categories. For GWP, the multi-storey apartment presented the lowest environmental impact $\left(2.28 \mathrm{E}+03 \mathrm{~kg} \mathrm{CO}_{2}\right.$ eq) due to its larger area, average population and fossil-based energy consumption profile compared with the single-family house $(3.26 \mathrm{E}+03 \mathrm{~kg} \mathrm{CO} 2 \mathrm{eq})$. Moreover, the LCA results showed that the majority of environmental impacts are originated from the operation phase (31-91\%) for both single-family house and multi-storey apartment building over their lifespan (50 years) due to fossil-based energy consumption for lighting, HVAC, running appliance and maintaining the comfort conditions regularly. A number of studies have considered LCA of several residential buildings in literature, however there is no study conducted to compare the overall environmental impacts of a single-family house and multi-storey apartment building in Turkey. This study aims to fill this gap and paves the way for further studies. As a suggestion for future studies, life cycle sustainability assessment can be applied on residential buildings by considering environmental, economic, and social aspects for more comprehensive assessment. Also, several residential buildings can be compared with life cycle sustainability assessment in further studies.

\section{Declarations}

\section{Ethic approval and consent to participate}

Not Applicable

\section{Consent for publication}

Not Applicable

\section{Availability of data and material}

The data used in the manuscript are included in the Supporting Information file. Additional data are available upon request from corresponding author Nigmet Uzal (nimetuzal@gmail.com).

\section{Competing interest}

The authors declare no competing interests

\section{Funding}

The authors did not receive financial support from any organization for the submitted work.

\section{Author Contribution}


All authors contributed to the design of this study as follows: NU developed and supervised the study; TV and MGK collect the data and performed data analysis; SG performed LCA analysis and drafted the manuscript. All authors were responsible for analyzing and interpreting the data and writing manuscript.

\section{References}

1. Alvarez-Rodriguez C, Martin-Gamboa M, Iribarren D (2019) Combined use of Data Envelopment Analysis and Life Cycle Assessment for operational and environmental benchmarking in the service sector: A case study of grocery stores. Sci Total Environ 667:799-808

2. Asdrubali F, Baldassarri C, Fthenakis V (2013) Life cycle analysis in the construction sector: Guiding the optimization of conventional Italian buildings. Energ Buildings 64:73-89

3. Atmaca A, Atmaca N (2015) Life cycle energy (LCEA) and carbon dioxide emissions (LCCO(2)A) assessment of two residential buildings in Gaziantep, Turkey. Energ Buildings 102:417-431

4. Atmaca A (2016) Life cycle assessment and cost analysis of residential buildings in south east of Turkey: part 1-review and methodology. Int J Life Cycle Assess 21:831-846

5. Atmaca N (2017) Life-cycle assessment of post-disaster temporary housing. Building Research and Information 45:524-538

6. Azari R (2014) Integrated energy and environmental life cycle assessment of office building envelopes. Energ Buildings 82:156-162

7. Blengini GA, Di Carlo T (2010) The changing role of life cycle phases, subsystems and materials in the LCA of low energy buildings. Energ Buildings 42:869-880

8. Chakraborty D, Elzarka H, Bhatnagar R (2016) Generation of accurate weather files using a hybrid machine learning methodology for design and analysis of sustainable and resilient buildings. Sustain Cities Soc 24:33-41

9. Chen C, Habert G, Bouzidi Y, Jullien A, Ventura A (2010) LCA allocation procedure used as an incitative method for waste recycling: An application to mineral additions in concrete. Resour Conserv Recy 54:1231-1240

10. Dara C, Hachem-Vermette C, Assefa G (2019) Life cycle assessment and life cycle costing of container-based single-family housing in Canada: A case study. Build Environ 163

11. de Magalhaes RF, Danilevicz ADF, Saurin TA (2017) Reducing construction waste: A study of urban infrastructure projects. Waste Manag 67:265-277

12. Ding ZK, Zhu ML, Tam VWY, Yi GZ, Tran CNN (2018) A system dynamics-based environmental benefit assessment model of construction waste reduction management at the design and construction stages. J Clean Prod 176:676-692

13. Dong YH, Ng ST, Liu P (2021) A comprehensive analysis towards benchmarking of life cycle assessment of buildings based on systematic review.Building and Environment204 
14. Ecoinvent (2013) : Ecoinvent 3.1 database Switzerland

15. Elzarka HM, Yan HY, Chakraborty D (2017) A vague set fuzzy multi-attribute group decision-making model for selecting onsite renewable energy technologies for institutional owners of constructed facilities. Sustain Cities Soc 35:430-439

16. Evangelista PPA, Kiperstok A, Torres EA, Goncalves JP (2018) Environmental performance analysis of residential buildings in Brazil using life cycle assessment (LCA). Constr Build Mater 169:748-761

17. Finkbeiner M, Inaba A, Tan RBH, Christiansen K, Kluppel HJ (2006) The new international standards for life cycle assessment: ISO 14040 and ISO 14044. Int J Life Cycle Ass 11:80-85

18. Gagg CR (2014) Cement and concrete as an engineering material: An historic appraisal and case study analysis. Eng Fail Anal 40:114-140

19. Hernandez P, Oregi X, Longo S, Cellura M (2019) Life-Cycle Assessment of Buildings. Handbook of Energy Efficiency in Buildings: A Life Cycle Approach, 207-261

20. Hollberg A, Ruth J (2016) LCA in architectural design-a parametric approach. Int J Life Cycle Ass 21:943-960

21. IEA (2008) Energy Technology Perspectives - Scenarios \& Strategies to 2050. IEA Publications, Paris, France

22. Konig H, De Cristofaro ML (2012) Benchmarks for life cycle costs and life cycle assessment of residential buildings. Build Res Inf 40:558-580

23. Lee C, Won JW, Jang W, Jung W, Han SH, Kwak YH (2017) Social conflict management framework for project viability: Case studies from Korean megaprojects. Int J Proj Manag 35:1683-1696

24. Lewandowska A, Noskowiak A, Pajchrowski G (2013) Comparative life cycle assessment of passive and traditional residential buildings' use with a special focus on energy-related aspects. Energ Buildings 67:635-646

25. Lu HYR, El Hanandeh A, Gilbert BP (2017) A comparative life cycle study of alternative materials for Australian multi-storey apartment building frame constructions: Environmental and economic perspective. J Clean Prod 166:458-473

26. Lu K, Jiang XY, Tam VWY, Li MY, Wang HY, Xia B, Chen Q (2019) Development of a Carbon Emissions Analysis Framework Using Building Information Modeling and Life Cycle Assessment for the Construction of Hospital Projects. Sustainability-Basel 11

27. Mangan SD, Oral GK (2015) A Study on Life Cycle Assessment of Energy Retrofit Strategies for Residential Buildings in Turkey. 6th International Building Physics Conference (Ibpc 2015) 78, 842847

28. Mangan SD, Oral GK (2016) Assessment of residential building performances for the different climate zones of Turkey in terms of life cycle energy and cost efficiency. Energ Buildings 110:362376

29. Mehta S, Chandur A, Palaniappan S (2017) Life Cycle Energy Assessment of a Multi-storey Residential Building. Journal of The Institution of Engineers (India): Series A 98:155-162 
30. Monahan J, Powell JC (2011) An embodied carbon and energy analysis of modern methods of construction in housing A case study using a lifecycle assessment framework. Energy Build 43:179188

31. Monteiro H, Freire F (2012) Life-cycle assessment of a house with alternative exterior walls: Comparison of three impact assessment methods. Energ Buildings 47:572-583

32. Norris GA (2001) Integrating life cycle cost analysis and LCA. Int J Life Cycle Ass 6:118-120

33. Petrovic B, Myhren JA, Zhang XX, Wallhagen M, Eriksson O (2019) Life cycle assessment of a wooden single-family house in Sweden.Appl Energ251

34. ReCiPe (2018) LCIA: the ReCiPe model

35. Rossi B, Marique AF, Glaumann M, Reiter S (2012) Life-cycle assessment of residential buildings in three different European locations, basic tool. Build Environ 51:395-401

36. Stephan A, Crawford RH, de Myttenaere K (2012) Towards a comprehensive life cycle energy analysis framework for residential buildings. Energy Build 55:592-600

37. Van Ooteghem K, Xu L (2012) The life-cycle assessment of a single-storey retail building in Canada. Build Environ 49:212-226

38. Wang J, Yu C, Pan W (2018) Life cycle energy of high-rise office buildings in Hong Kong. Energ Buildings 167:152-164

39. WorldSteelAssociation (2008) Sustainability Report of the world steel industry, Brussels, Belgium

40. Yung P, Wang XY (2014) A 6D CAD Model for the Automatic Assessment of Building Sustainability (vol 11, pg 131, 2014).Int J Adv Robot Syst11

41. Zhang WQ, Tan S, Lei YZ, Wang SB (2014) Life cycle assessment of a single-family residential building in Canada: A case study. Build Simul-China 7:429-438

\section{Figures}

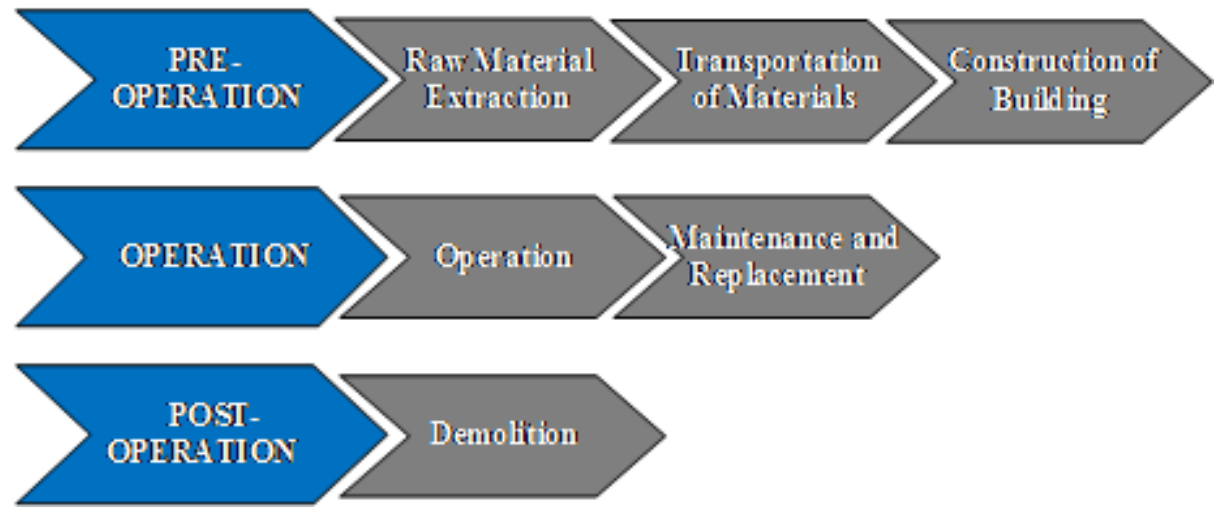

Figure 1

System boundaries of the single-family house and multi-storey apartment 


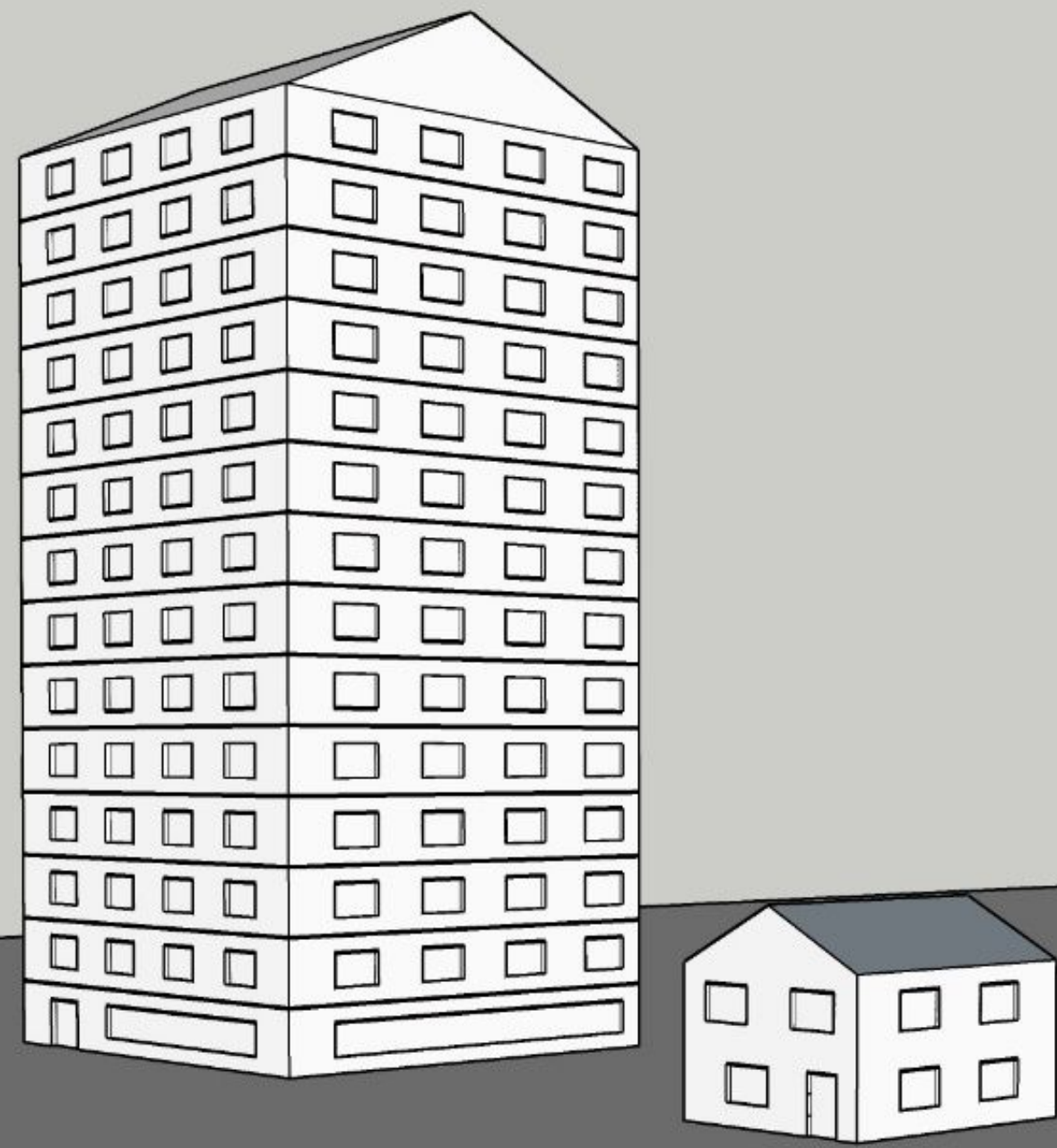

\section{Figure 2}

3D models of single-family house and multi-storey apartment 


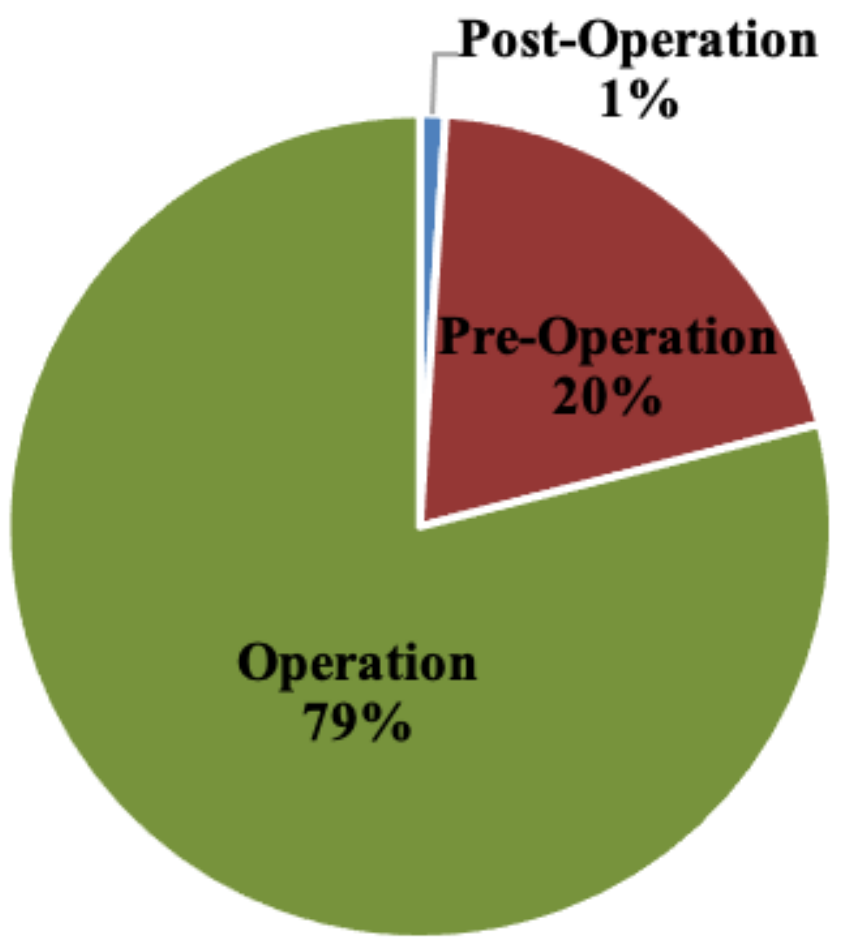

Figure 3

The distribution of GWP by processes for single-family house

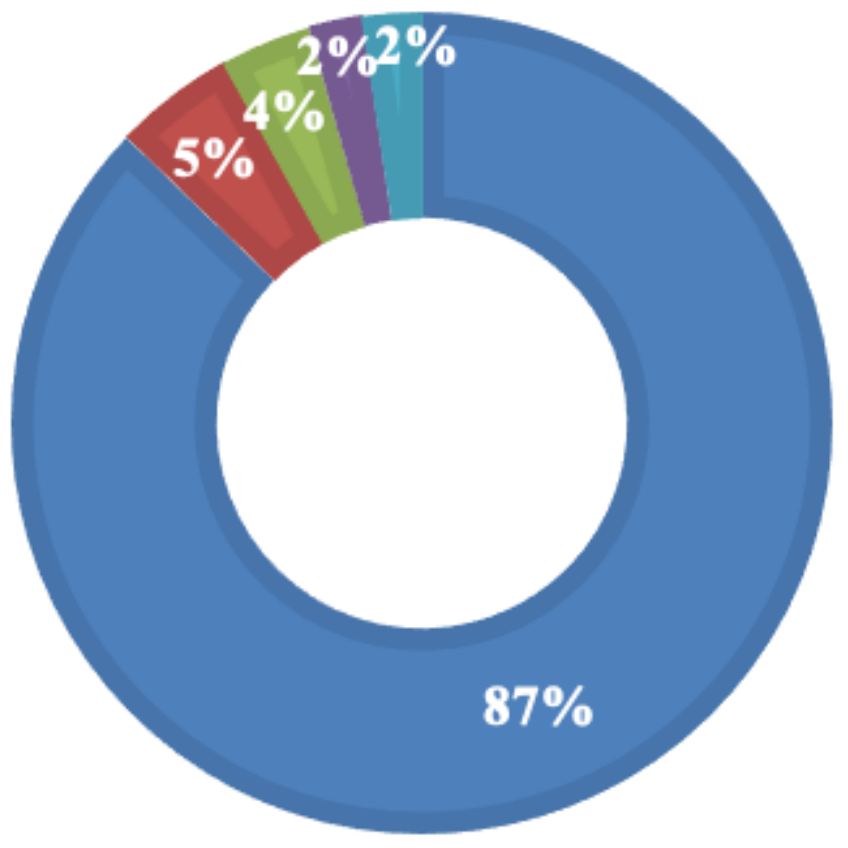

Electricity

n Solid Waste

n Water

- Natural Gas

n Others

Figure 4

The distribution of GWP by sub-components of single-family house for operation phase 


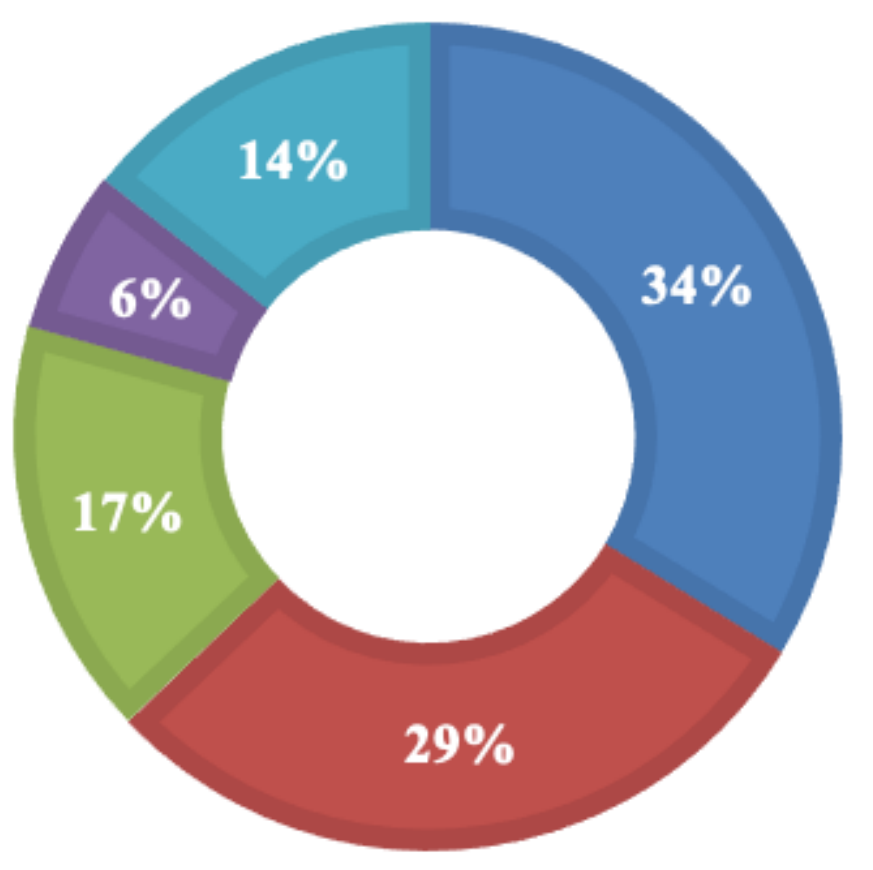

- Steel

Concrete

Transportation

Brick

Others

Figure 5

The distribution of GWP by sub-components of single-family house for pre-operation phase

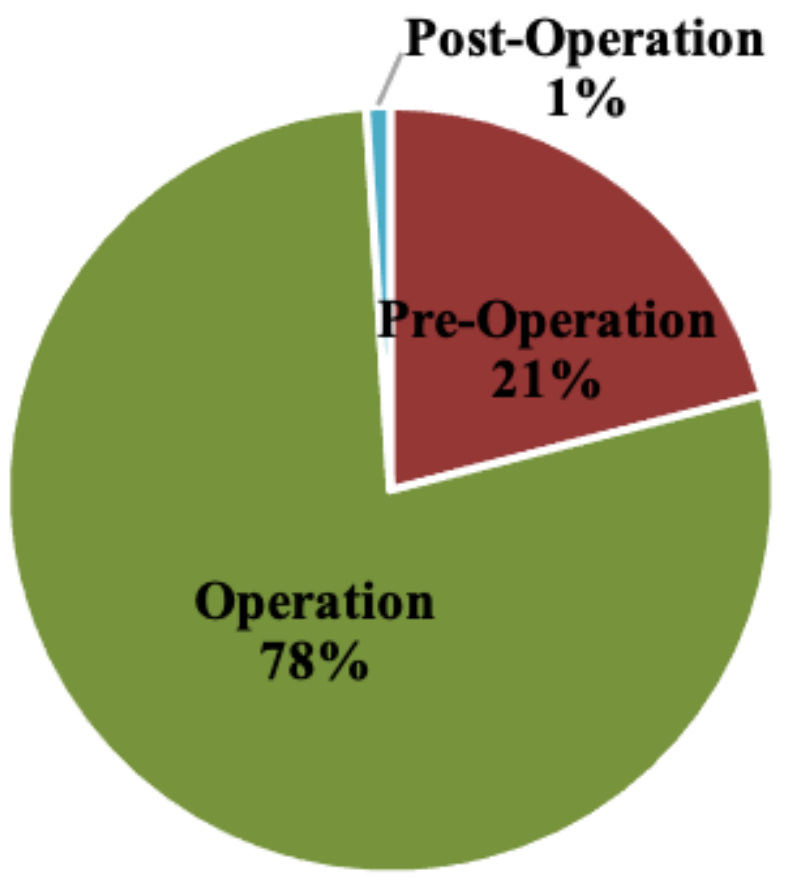

Figure 6

The distribution of GWP by processes for multi-storey apartment 


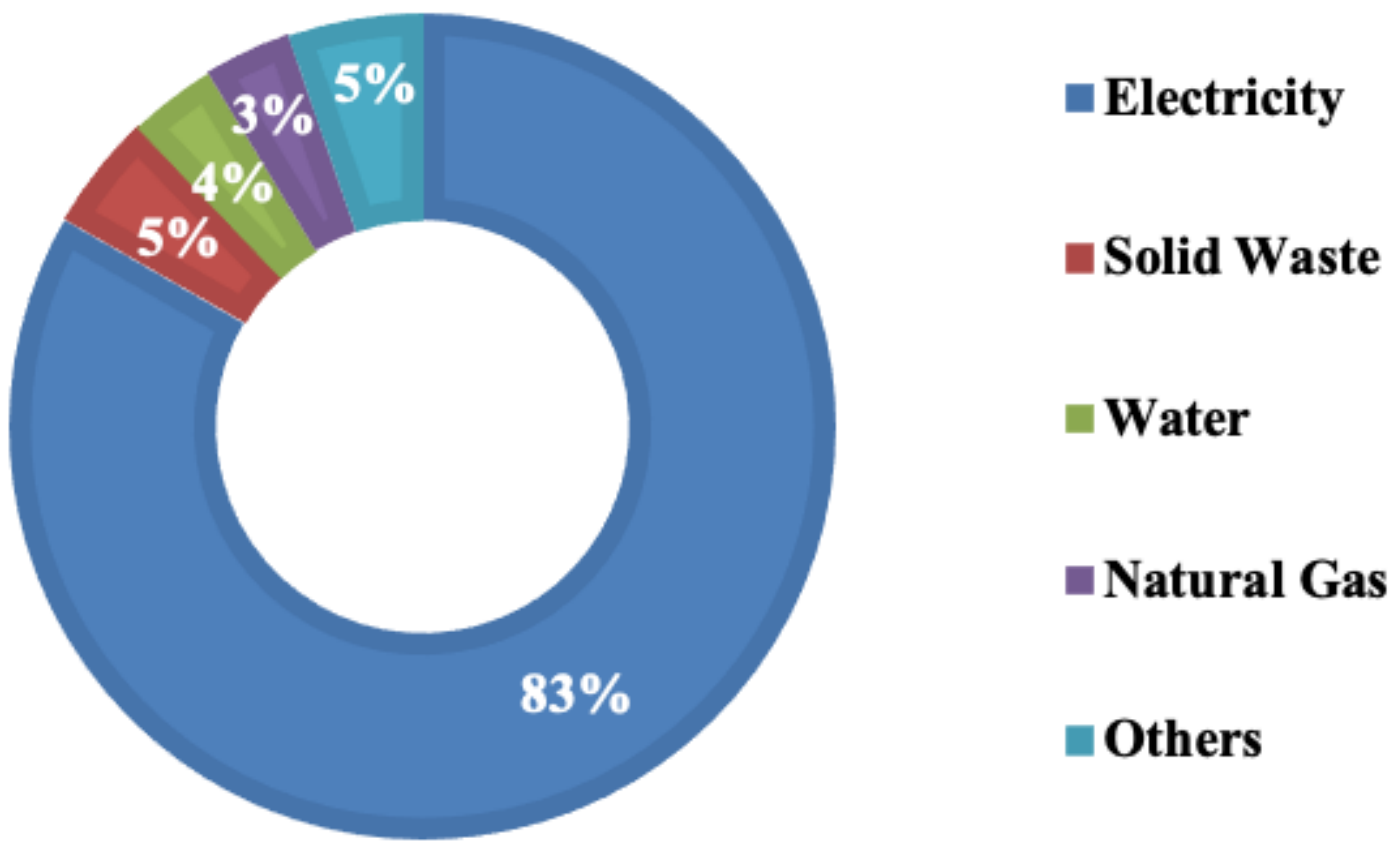

Figure 7

The distribution of GWP by sub-components of multi-storey apartment for operation phase

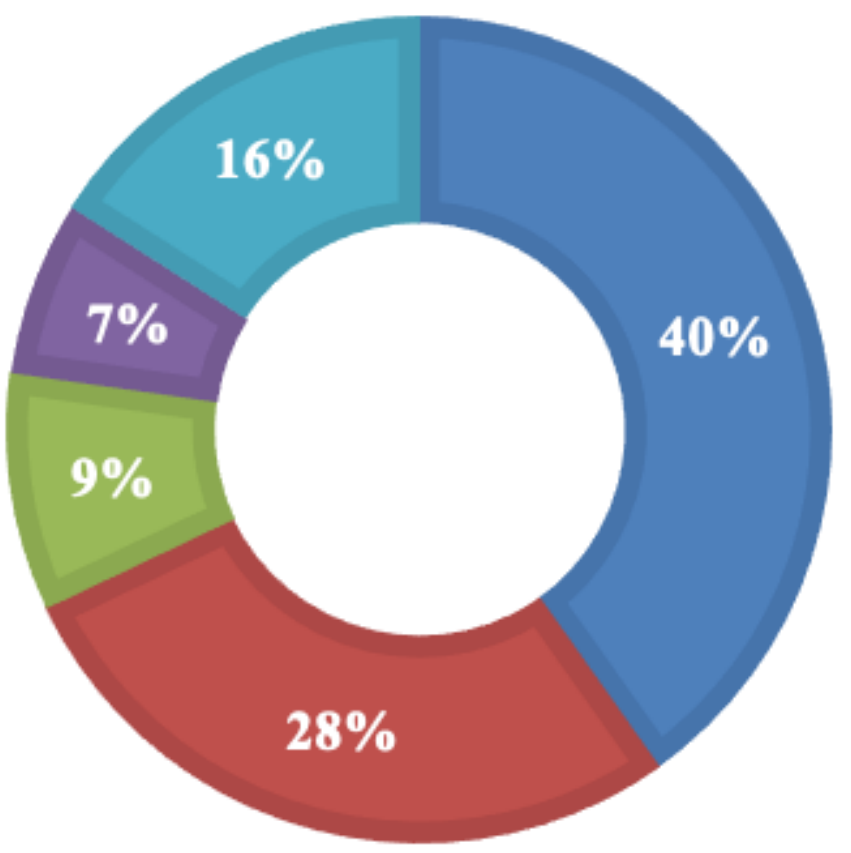

- Steel

- Concrete

Transportation

cable

nOthers

Figure 8

The distribution of GWP by sub-components of multi-storey apartment for pre-operation phase 


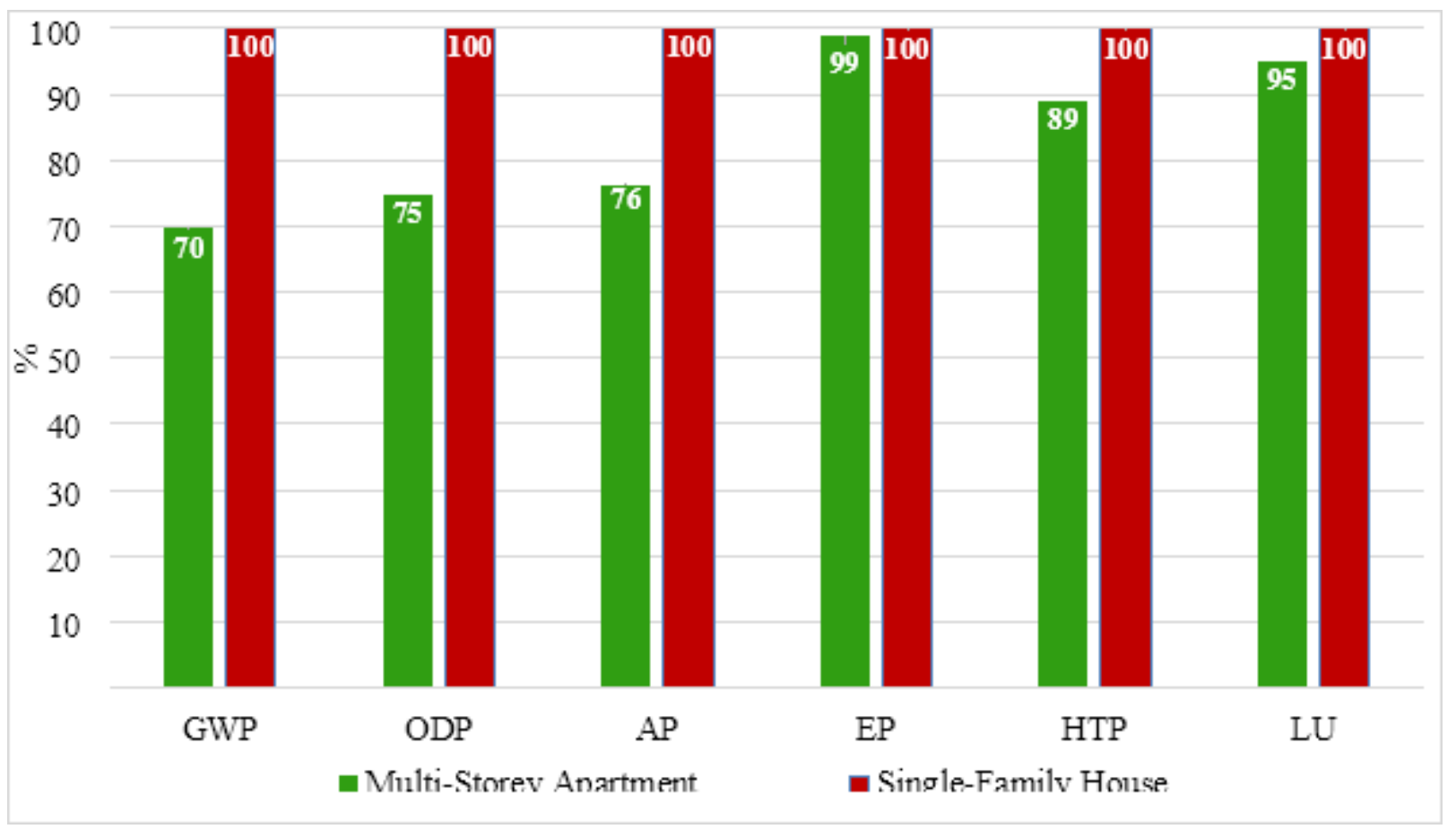

Figure 9

The comparison of environmental impacts of multi-storey apartment and single-family house based on ReCiPe method: ReCiPe 2016 Midpoint (H) V1.00/Characterization (GWP: Global Warming Potential, ODP: Ozone Layer Depletion, AP: Acidification Potential, EP: Eutrophication Potential, HTP: Human Toxicity Potential, LU: Land Use)

\section{Supplementary Files}

This is a list of supplementary files associated with this preprint. Click to download.

- gulcimenetalsupplementarymaterialsESPR.docx 